\title{
Revisiting the Dynamics of the Fiscal Deficit and Inflation in India: the Nonlinear Autoregressive Distributed Lag Approach ${ }^{1}$
}

The chronic government deficit (fiscal deficit) and increase in the price level (inflation) have become major concerns for economists and policymakers. While numerous studies have examined the twin problems of the fiscal deficit and inflation for both developed and developing economies, their results are inconclusive due to different estimation techniques, chosen time periods, selection of variables, etc. Therefore, we examined the fiscal deficit-inflation nexus in India for the period from 1980-81 to 2016-17 by employing the Autoregressive Distributed Lag (ARDL) and Nonlinear Autoregressive Distributed Lag (NARDL) approaches. The results of the ARDL approach found no evidence of linear relationship between fiscal deficit and inflation in the Indian context. Further, the empirical findings of the NARDL model confirmed the nonlinear relationship between fiscal deficit and inflation in the long run and no association between money supply and inflation, supporting the ideas of the Fiscal Theory of the Price Level (FTPL) in the case of India. FTPL postulates that public debt and taxation policies drive price level; monetary policy has an indirect role only. Therefore, fiscal policymakers should focus on reducing fiscal deficits. Simultaneously, the Reserve Bank of India (RBI) should regulate lending interest rate so that a mix of fiscal and monetary policies can be applied for controlling inflation in India.

Keywords: fiscal policy, monetary policy, fiscal deficit, Wholesale Price Index, money supply, crude oil prices, Fiscal Theory of the Price Level, interest rate, cointegration, ARDL Approach, NARDL Approach

For citation: Sharma, V. \& Mittal, A. (2021). Revisiting the Dynamics of the Fiscal Deficit and Inflation in India: the Nonlinear Autoregressive Distributed Lag Approach. Ekonomika regiona [Economy of region], 17(1), 318-328, https://doi. org/10.17059/ekon.reg.2021-1-24

${ }^{1}$ (c) Sharma V., Mittal A. Text. 2021. 


\title{
В. Шарма ${ }^{\text {a) }}$, А. Миттал б) \\ a) Университет GLA, Матхура, Индия \\ 6) Алигархский мусульманский университет, Алигарх, Индия a) https://orcid.org/0000-0003-3612-7241, e-mail: economics.vishal26@gmail.com
}

\section{Динамика бюджетного дефицита и инфляции в Индии: нелинейная модель авторегрессии и распределенного лага}

\begin{abstract}
Хронический дефицит государственного бюджета и рост уровня иен становятся предметом активньх обсуждений как экономистов, так и представителей власти. Результаты многочисленных исследований, посвященных анализу данной темы, в контексте развитых и развивающихся стран неоднозначнь, поскольку при анализе используются различные методы оценки, выборки временных периодов и переменных и др. В настоящей статье исследуется взаимосвязь между бюджетным дебииитом и инбляицей в Индии в период с 1980-1981 по $2016-2017$ г2. Для этой цели были использованы модель авторегрессии и распределенного тага (ARDL) и нелинейная модель авторегрессии и распределенного лага (NARDL). В результате применения модели ARDL линейная связь между бюджетным дефицитом и инбляцией в контексте Индии не обнаружена. Однако эмпирические результаты, полученные при помощи NARDL, подтвердили существование нелинейной связи между бюджетным дефицитом и инфляцией в долгосрочной перспективе и отсутствие связи между денежными ресурсами и инфляцией. Данный результат подтверждает положения фискальной теории уровня цен, согласно которой государственный долг и налоговая политика определяют уровень иен, а денежно-кредитная политика играет лишь косвенную роль. Следовательно, при планировании налогово-бюджетной политики следует сосредоточить внимание на сокращении бюджетного дефиицтал. В то же время, Резервный банк Индии (RBI) должен сбокусироваться на регулировании прои,нтной ставки по ссудам. Данные меры необходимь, чтобы обеспечить сочетание налогово-бюджетной и денежно-кредитной политики для контроля инфляции в Индии.
\end{abstract}

Ключевые слова: налогово-бюджетная политика, денежно-кредитная политика, бюджетный дефицит, индекс оптовых цен, денежные ресурсы, цены на сырую нефть, фискальная теория уровня цен, процентная ставка, коинтеграция, модель авторегрессии и распределенного лага, нелинейная модель авторегрессии и распределенного лага

Для цитирования: Шарма, В., Миттал, А. Динамика бюджетного дефицита и инфляции в Индии: нелинейная модель авторегрессии и распределенного лага // Экономика региона. 2021. Т. 17, вып. 1. С. 318-328. https://doi.org/10.17059/ ekon.reg.2021-1-24

\section{Introduction}

Harmonisation of fiscal and monetary policies is required to achieve macroeconomic stability in an economy. Otherwise, the uncertain nature of some macroeconomic variables would have an adverse impact on the overall economy [1]. The chronic government deficit (fiscal deficit) and increase in the price level (inflation) have become major concerns in both developed and developing economies. A large fiscal deficit increases not only public debt but also inflationary pressure on the economy [2-4]. According to [2], monetary authorities were able to curb the inflation rate, notably, in the long term, by controlling the money supply. Fiscal deficits can only lead to inflation if they are monetized. [3] argued that central bank would be required to finance the deficit via monetization either now or in the near future, resulting in an increase in money supply and the inflation rate in the long run. [4] noted that the rapid growth of money supply without fiscal deficit is rare, implying that the inflation rate is always a fiscal phenomenon. An alternative view, explored by [5], stated that deficit influences the inflation dynamics of an economy, irrespective of whether the deficits are monetized. He argued that deficit financing could be done through private monetization and/or crowding out. In fact, non-monetized deficits, i. e., bond-financed deficits resulted in a higher rate of interest leading to crowding out of private investment and reducing the real output growth rate, increasing the price level in the economy.

Since the early 1990s, the Indian economy has undergone several changes in the fiscal-monetary policy. These include elimination of automatic monetization of the fiscal deficit via the creation of ad hoc treasury bills in 1997 and prohibiting the Reserve Bank of India (RBI) from purchasing government securities in the primary market under the Fiscal Responsibility and Budget Management (FRBM) Act, 2003 [6]. Such significant alterations have changed the fiscal-monetary policy. However, large fiscal deficits continue to be incurred by the central government influencing demand management by the RBI. Therefore, the dynamics of the fiscal deficit and inflation are now centre stage in India.

From a theoretical perspective, there are alternative views regarding the dynamics of the fiscal deficit and inflation. The Keynesian Theory, based on aggregate demand - aggregate supply 


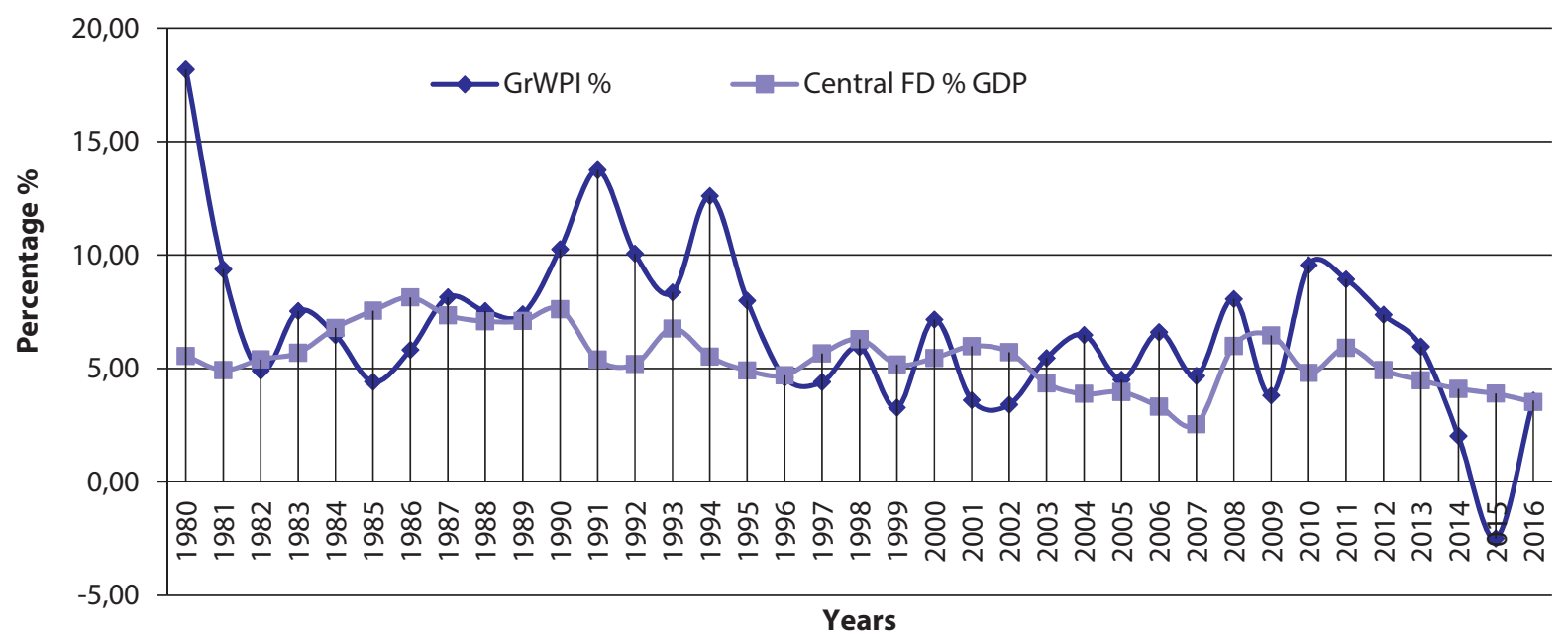

Source: Author's Compilation based on RBI database on Indian Economy, 2017.

Note: GrWPI\% — Growth rate of Wholesale Price Index, Central FD\%GDP — Fiscal Deficit (as a percentage of GDP) of the Central Government

Fig. 1. Fiscal Deficit and Inflation Trends in India

function, stated that the situation when aggregate demand exceeds aggregate supply leads to a rise in the price level of an economy. However, this only occurs when the economy attained full employment. Quantity Theory of Money, also known as the Monetarist Hypothesis, is encapsulated in the well-known statement that "inflation is always and everywhere a monetary phenomenon" [2]. Contrary to the theory of monetarists, Fiscal Theory of the Price Level postulated that the price level is driven by public debt and taxation policies; monetary policy plays only an indirect role [7].

There are numerous empirical studies examining the twin problems of the fiscal deficit and inflation for both developed and developing economies. Some studies have supported the idea that there is a strong relationship between fiscal deficit and inflation [1; 8-30]. Alternatively, other studies deny the existence of a connection between the two [31-35]. Along with the fiscal deficit, money supply is also considered as an essential factor in determining the price level in an economy. Some studies, including [36-37], found that money supply influences the inflation rate in India. Crude oil prices are also recognised as the major determinant of the domestic price level and output. Studies like [38-41] revealed that oil prices have a positive impact on the inflation rate and have an adverse impact on output in India.

It may be observed from the above studies that the results on the relationship between fiscal deficit and inflation are inconclusive due to different estimation techniques, different time periods, selection of variables, etc. The present study examines the fiscal deficit-inflation nexus in India during 1980-81 to 2016-17 using both Autoregressive Distributed Lag (ARDL) approach to Cointegration
[42] and Nonlinear Autoregressive Distributed Lag (NARDL) Bounds Testing of Cointegration [43]. Other macroeconomic variables such as oil prices, money supply and interest rate are also considered for the analysis.

The study is structured as follows. Section 2 describes the growth pattern of fiscal deficit and inflation in India. Section 3 proposes a description of the dataset and variables. Section 4 discusses the research methodology, model specifications of ARDL and NARDL approach and empirical analysis of both models. Section 5 presents the summary and concluding remarks.

\section{Fiscal Deficit and Inflation: Recent Trends}

The phenomena of the fiscal deficit and inflation have acquired a prominent place in the development of government policy measures in India. Consequently, it is necessary to examine the direction of both variables in the Indian context. Figure 1 depicts the movement of the fiscal deficit of the central government, which has been taken as the percentage of gross domestic product $(G D P)$ and also shows the rate of growth of wholesale price index (GrWPI) in the period from $1980-81$ to $2016-17$. In the early phase, a high inflation rate at $18.2 \%$ is observed. In the successive years, the rate has reduced, but it outpaced the double-digit during the early '90s. In 1994-95, the government succeeded in decreasing the inflation rate to a single digit, and this level was retained until the mid-2000s. After 2008, an increasing trend was observed with the exception of one year in the middle; the rate reached almost double digits in 2010-11. However, the extent of the fiscal deficit was maintained at a viable level up to the early ' 80 s. However, in the period from the 
Descriptive Statistics (in billion rupees)

\begin{tabular}{|c|c|c|c|c|c|c|c|}
\hline Variables & Mean & Median & Max & Min & Std. Dev. & Skewness & Kurtosis \\
\hline$W P I^{*}$ & 83.77 & 75.12 & 183.00 & 19.69 & 52.39 & 0.55 & 2.10 \\
\hline$C F D$ & 1664.51 & 1047.16 & 5342.74 & 82.99 & 1820.60 & 1.12 & 2.64 \\
\hline$G r M S$ & 27929.64 & 9809.60 & 127919.40 & 557.74 & 36842.38 & 1.41 & 3.74 \\
\hline$O P^{* *}$ & 40.83 & 28.55 & 105.01 & 13.06 & 29.33 & 1.14 & 2.94 \\
\hline LIR $^{* * *}$ & 13.75 & 13.54 & 18.91 & 8.33 & 2.84 & -0.09 & 1.68 \\
\hline
\end{tabular}

Note: ${ }^{*} W P I$ is in the index form, ${ }^{* *} O P$ measures in US\$/barrel, ${ }^{* * *} L I R$ is in the percentage form.

mid-1980s to the mid-1990s, the fiscal deficit once again became a matter of grave concern for the government. The level of deficit nearly reached double digits in 2002-03 despite all efforts made by the government. To regulate the fiscal deficit, the Government of India adopted the fiscal correction mechanism and implemented an act, namely, FRBM Act 2003, thereafter decreasing and maintaining the level of fiscal deficit until 2008. Furthermore, with the emergence of the global financial meltdown, again, the deficit has significantly increased. Therefore, it becomes clear that there is a positive relationship between fiscal deficit and inflation mostly in all years with the exception of the early 1980s and the mid-2000s.

In the beginning of the 1980s, significant factors contributing to inflationary pressure were increased oil prices and shortage of food supply due to deficient agricultural production [44]. Although there was a significant decrease in the fiscal deficit level, inflation was quite high during 1991-92 and 1994-95. The primary cause of this trend was globalisation and weak Indian currency against the dollar (depreciation of Indian currency), which stimulated the massive inflow of capital resulting in inflation. Additionally, another vital reason was a price hike of necessary commodities due to insufficient supply, which added to a rise in inflation levels. The inflation pressure in the economy was substantially controlled by the thorough structural reforms. Thus, fiscal deficit and inflation are moving in the same direction except for some previously mentioned years.

\section{Variables and Data Sources}

This study investigates the dynamics of the fiscal deficit and inflation in India using annual data from 1980-81 to 2016-17. Other macroeconomic variables such as oil prices, money supply, and interest rate are also considered for the analysis. Wholesale price index (WPI) of all commodities is taken for inflation because, in India, major policy changes were based on the level of inflation. Other studies have used the call money rate, Treasury bill rate, etc. for the interest rate variable. However, in this study, we chose the com- mercial bank lending rate (LIR), as the fiscal deficit has a negative influence on the lending rate of commercial banks, which, in turn, adversely affects output and inflation. The growth rate of the money supply (GrMS) is taken as an indicator of the money supply. Crude oil prices $(O P)$ are considered as a proxy for oil prices. The fiscal deficit of the central government (CFD) was chosen for the fiscal deficit. The time-series data of the selected variables are extracted from the Reserve Bank of India (RBI).

To assess the fiscal deficit-inflation nexus, we have developed the following log-linear equation:

$$
\begin{aligned}
W P I_{t}= & \alpha_{0}+\beta_{1} C F D_{t}+\beta_{2} G_{M S}+ \\
& +\beta_{3} O P_{t}+\beta_{4} L I R_{t}+\varepsilon_{t},
\end{aligned}
$$

where $W P I=$ Wholesale Price Index CFD = Fiscal Deficit of the Central Government as a percentage of GDP; GrMS = Growth rate of the money supply; $O P=$ Crude oil prices as US\$ per barrel; $L I R=$ Lending Interest Rate in the percentage form; $\varepsilon=$ Error Term, $t=$ Time Period.

The descriptive statistics of all variables used in the model are provided in Table 1 . For examining and determining the statistical behaviour of these variables, descriptive statistics were calculated.

\section{Model Specification and Empirical Analysis}

\subsection{Auto-Regressive Distributed Lag (ARDL) approach to Cointegration}

The dependent variable considered in the ARDL model is a function of its own past lagged values along with the past and current values of other explanatory variables. The ARDL model was introduced and developed by [46] and was revised by [47]. It has been extensively used because it has various advantages over traditional statistical methods which were used for assessing cointegration and short/long-run relationships, irrespective of the underlying variables I(0), I(1) or a combination of both. The ARDL model cannot be applied when the variables are integrated of order two I(2). Combining I(0) and I(1) variables can be 
Unit Root Tests

\begin{tabular}{|c|c|c|c|c|}
\hline \multirow{2}{*}{ Variables } & \multicolumn{2}{|c|}{ ADF Test } & \multicolumn{2}{c|}{ PP Test } \\
\cline { 2 - 5 } & Levels & 1st Difference & Levels & 1st Difference \\
\hline \multirow{2}{*}{ WPI } & 2.92 & $-3.18^{* *}$ & 2.18 & $-3.15^{* *}$ \\
& $(1.00)$ & $(0.02)$ & $(0.99)$ & $(0.02)$ \\
\hline \multirow{2}{*}{ CFD } & -2.23 & $-6.45^{* * *}$ & -2.20 & $\left(0.65^{* * *}\right.$ \\
& $(0.19)$ & $(0.00)$ & -1.55 & $-6.00)$ \\
\hline \multirow{2}{*}{$O P$} & -1.51 & $-6.30^{* * *}$ & $(0.50)$ & $(0.00)$ \\
\hline \multirow{2}{*}{$G r M S$} & $(0.52)$ & $(0.00)$ & $-3.17^{* *}$ & - \\
\hline \multirow{2}{*}{$L I R$} & $-3.01^{* *}$ & - & $(0.02)$ & $-5.95^{* * *}$ \\
& $(0.03)$ & $-5.71^{* * *}$ & -0.59 & $(0.00)$ \\
\hline
\end{tabular}

Source: Author's compilation.

Note: $p$-values are in the parenthesis, ${ }^{* *} \&{ }^{* * *}$ represent 5 and 1 percent level of significance, respectively.

an advantage because time series are either integrated of order I(1) or I(0).

Further, the ARDL approach integrates the short-run impact of the variables with the longrun equilibrium with the help of an error correction term, making it easier to assess both shortrun and long-run relationship among the variables. Unlike traditional cointegration tests, it is possible to estimate different lags for different variables used in the model [47], enhancing its flexibility. As most cointegration techniques are sensitive to the sample size, the ARDL method gives consistent results for small sample sizes $[46,47]$.

To apply the ARDL model, it is necessary to test the null hypothesis of no cointegration (i. e. H0: $a_{1}=a_{2}=a_{3}=a_{4}=a_{5}=0$ ); to test the alternative hypothesis, it is necessary to use the $F$-test with critical values tabulated by [47]. Under the null hypothesis of no cointegration relationship among the variables, the asymptotic distributions of the $F$-statistics are non-standard, irrespective of the variables being purely $\mathrm{I}(0)$ or I(1), or mutually cointegrated. [47] has provided two sets of asymptotic critical values. It is assumed that all variables are $\mathrm{I}(0)$ in the first set and all variables are $\mathrm{I}(1)$ in the second set. If the calculated $F$-statistic is greater than the upper bound critical value, the null hypothesis of no cointegration will be rejected. Alternatively, if it is less than the lower bound critical value, the null hypothesis of no cointegration will be accepted. Finally, the result is neither accepted nor rejected if the computed $F$-statistic falls within the lower and upper bound critical values. In such cases, it is possible to establish cointegration using the error correction term.

To estimate the long-run coefficient, the ARDL model can be presented as:

$$
\begin{gathered}
W P I_{t}=a_{0}+\sum_{i=1}^{p} a_{1} W P I_{t-i}+\sum_{i=0}^{q} a_{2} \operatorname{CFD}_{t-i}+ \\
+\sum_{i=0}^{q} a_{3} G r M S_{t-i}+\sum_{i=0}^{q} a_{4} O P_{t-i}+\sum_{i=0}^{q} a_{5} L I R_{t-i}+u_{t},
\end{gathered}
$$

Where, $a_{0}$ represents intercept; $a_{1}$ to $a_{5}$ denote long-run coefficients; $p \& q$ are the lags of endogenous and exogenous variables, respectively, and $u_{t}$ stands for the residual term.

Further, error correction representation of the ARDL model can be written as:

$$
\begin{gathered}
\Delta W P I_{t}=a_{0}+\sum_{i=1}^{p} b_{1} \Delta W P I_{t-i}+\sum_{i=0}^{q} b_{2} \Delta C F D_{t-i}+ \\
+\sum_{i=0}^{q} b_{3} \Delta G r M S_{t-i}+\sum_{i=0}^{q} b_{4} \Delta O P_{t-i}+\sum_{i=0}^{q} b_{5} \Delta L I R_{t-i}+ \\
+\phi E C M_{t-1}+\omega_{t},
\end{gathered}
$$

where, $\Delta$ denotes the first difference; $b_{1}$ to $b_{5}$ represent short-run coefficients; $E C M_{t-1}$ is the error correction term, $\phi$ shows the speed of adjustment and $\omega_{t}$ stands for the residual term.

\subsection{Empirical Analysis}

For determining the unit root properties of the data, we used two traditional tests: the Augmented Dickey-Fuller $(A D F)$ test [45] and Phillips-Perron $(P P)$ test (Phillips, et al., 1988)[46]. The results are provided in Table 2 .

From Table 2, $A D F$ and $P P$ tests show that GrMS is stationary at levels, i. e. I(0), and the rest of the variables are stationary at the first difference, i. e. I(I). Therefore, mixed order of integration, i. e. I(0) and I(1), validates the implementation of the ARDL bounds testing approach to cointegration.

We used the bounds test for cointegration and the results are reported in Table 3 . Since the 
Table 3

Bounds Test for Cointegration

\begin{tabular}{|l|c|c|c|c|}
\hline Test-statistics & Value & Significance, $\%$ & I (0) & I (1) \\
\hline$F$-statistics & 7.18 & 5 & 2.56 & 3.49 \\
\hline$k$ & 4 & 10 & 2.20 & 3.09 \\
\hline
\end{tabular}

Source: Author's compilation.

Diagnostic Tests

\begin{tabular}{|l|c|c|}
\hline \multicolumn{1}{|c|}{ Residuals Diagnostic Test } & Statistics & $\boldsymbol{p}$-value \\
\hline Serial Correlation test & 0.04 & 0.95 \\
\hline Heteroskedasticity test & 1.61 & 0.23 \\
\hline Normality Test & 0.26 & 0.87 \\
\hline
\end{tabular}

Source: Author's compilation.

Table 5

Long Run Estimates of the ARDL Model

\begin{tabular}{|c|c|c|c|}
\hline Variables & Coefficients & $\boldsymbol{t}$-Stats & $\boldsymbol{p}$-Value \\
\hline C & $181.58^{* *}$ & 7.33 & 0.00 \\
\hline CFD & 1.18 & 0.46 & 0.65 \\
\hline GrMS & 2.93 & 1.94 & 0.08 \\
\hline LIR & $-14.07^{* *}$ & -7.71 & 0.00 \\
\hline OP & -0.11 & -0.65 & 0.52 \\
\hline ECM $(-1)$ & $0.26^{* *}$ & 8.18 & 0.00 \\
\hline
\end{tabular}

Source: Author's compilation.

Note: ${ }^{* *}$ represent 5 percent level of significance.
F-statistics (7.18) are larger than the upper critical bound value (3.49) at 5 percent level of significance, we reject the null hypothesis of no cointegration. Therefore, the obtained results show that all variables are moving in the same direction in the long run.

The study has used the Akaike Information Criterion (AIC) for selecting the suitable lag length of the model. Figure 2 shows that the AIC has recommended the ARDL $(4,4,4,4,3)$ model for evaluating the long-run coefficients.

Furthermore, to assess the suitability of the model, we conducted some diagnostic tests (Table 4). The Breusch-Godfrey serial correlation $L M$ test and the Breusch-Pagan-Godfrey test reveal that the model is free from autocorrelation and heteroskedasticity in the residuals, respectively. The Jarque-Bera statistics show that the residual term is normally distributed.

Next, we estimated the long-run coefficients of the ARDL model; the results are shown in Table 5.

Table 5 shows that the coefficients of CFD and GrMS are positive, which is expected, but have an insignificant impact on WPI at 5 percent level of significance. This negates any relationship between CFD \& WPI and GrMS \& WPI in the context of India. The coefficient of $L I R$ is negative and has a

Akaike Information Criteria (top 20 models)

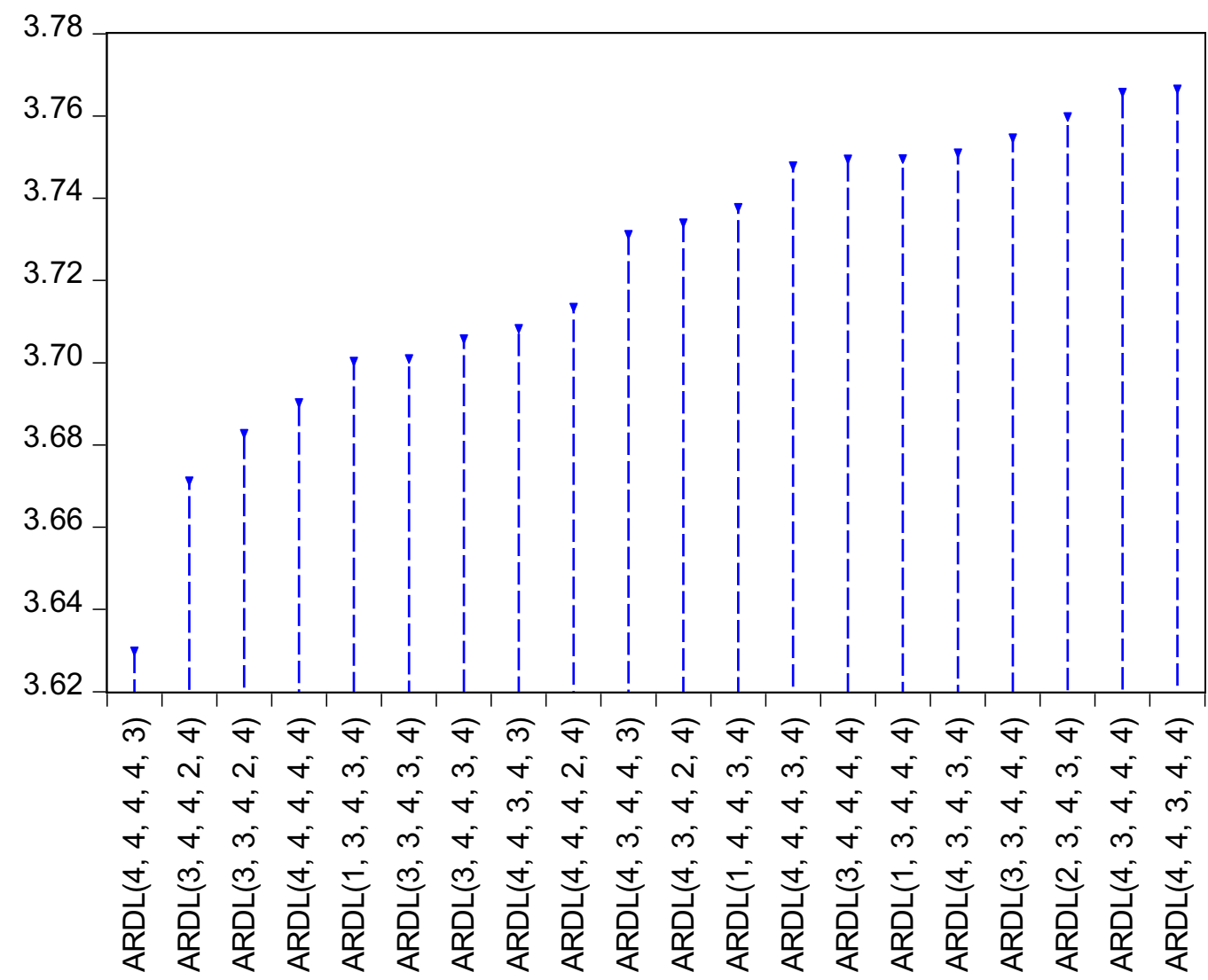

Fig. 2. Lag Selection Criteria 
significant impact on WPI at 5 percent level of significance. This implies that a 1 percent increase in $L I R$ will lead to a 14.07 percentage point decrease in WPI in the long run. Further, $O P$ has an insignificant impact on WPI at 5 percent level of significance. The coefficient of the error correction term $(E C M)$ is positively signed and significant at 5 percent level of significance. When ECM is positive, series will diverge instead of converging; therefore, there will be no long-run equilibrium.

Thus, the results of the ARDL approach found no evidence of linear/symmetric relationship between the fiscal deficit and inflation in the Indian context. Therefore, we decided to apply the Nonlinear Autoregressive Distributed Lag (NARDL) model introduced by [43] in order to verify the nonlinear/asymmetric relationship between the variables.

\subsection{Nonlinear Autoregressive Distributed Lag (NARDL) Bounds Testing of Cointegration}

The study has considered the general form of the NARDL model to test the asymmetric cointegration:

$$
\begin{gathered}
W P I_{t}=\alpha_{0}+\beta_{1}^{+} C F D_{t}^{+}+\beta_{2}^{-} C F D_{t}^{-}+ \\
+\beta_{3}^{+} O P_{t}^{+}+\beta_{4}^{-} O P_{t}^{-}+\beta_{5}^{+} G r M S_{t}^{+}+ \\
+\beta_{6}^{-} G r M S_{t}^{-}+\beta_{7}^{+} L I R_{t}^{+}+\beta_{8}^{-} L I R_{t}^{-}+\varepsilon_{t} .
\end{gathered}
$$

In equation (4), $C F D_{t}^{+} \& C F D_{t}^{-} ; O P_{t}^{+} \& O P_{t}^{-}$; $G r M S_{t}^{+} \& G r M S_{t}^{-}$and $L I R_{t}^{+} \& L I R_{t}^{-}$are the partial sum of positive and negative changes in fiscal deficit, oil prices, money supply and lending interest rate, respectively:

$$
\begin{aligned}
C F D_{t}^{+} & =\sum_{j=1}^{t} \Delta C F D_{j}^{+}=\sum_{j=1}^{t} \max \left(\Delta C F D_{j}, 0\right), \\
C F D_{t}^{-}=\sum_{j=1}^{t} \Delta C F D_{j}^{-} & =\sum_{j=1}^{t} \min \left(\Delta C F D_{j}, 0\right), \\
O P_{t}^{+} & =\sum_{j=1}^{t} \Delta O P_{j}^{+}=\sum_{j=1}^{t} \max \left(\Delta O P_{j}, 0\right), \\
O P_{t}^{-}=\sum_{j=1}^{t} \Delta O P_{j}^{-} & =\sum_{j=1}^{t} \min \left(\Delta O P_{j}, 0\right), \\
G r M S_{t}^{+}=\sum_{j=1}^{t} \Delta G r M S_{j}^{+} & =\sum_{j=1}^{t} \max \left(\Delta G r M S_{j}, 0\right), \\
G r M S_{t}^{-}=\sum_{j=1}^{t} \Delta G r M S_{j}^{-} & =\sum_{j=1}^{t} \min \left(\Delta G r M S_{j}, 0\right), \\
L I R_{t}^{+} & =\sum_{j=1}^{t} \Delta L I R_{j}^{+}=\sum_{j=1}^{t} \max \left(\Delta L I R_{j}, 0\right), \\
L I R_{t}^{-}=\sum_{j=1}^{t} \Delta L I R_{j}^{-} & =\sum_{j=1}^{t} \min \left(\Delta L I R_{j}, 0\right),
\end{aligned}
$$

[43] has modified equation (4); thus, we re-arranged the ARDL form along the line of [42] and [47] as:

$$
\begin{gathered}
\Delta W P I_{t}=\propto+\rho W P I_{t-1}+\omega_{1}^{+} C F D_{t-1}^{+}+ \\
+\omega_{2}^{-} C F D_{t-1}^{-}+\omega_{3}^{+} O P_{t-1}^{+}+\omega_{4}^{-} O P_{t-1}^{-}+\omega_{5}^{+} G r M S_{t-1}^{+}+ \\
+\omega_{6}^{-} G r M S_{t-1}^{-}+\omega_{7}^{+} L I R_{t-1}^{+}+\omega_{8}^{-} L I R_{(t-1)}^{-}+ \\
+\sum_{j=1}^{p-1} \delta_{j} \Delta W P I_{t-j} \sum_{j=0}^{q-1}\left(\begin{array}{c}
\theta_{j}^{+} \Delta C F D_{t-j}^{+}+\theta_{j}^{-} \Delta C F D_{t-j}^{-}+ \\
+\pi_{j}^{+} \Delta O P_{t-j}^{+}+\pi_{j}^{-} \Delta O P_{t-j}^{-}+ \\
+\phi_{j}^{+} \Delta G r M S_{t-j}^{+}+\phi_{j}^{-} \Delta G r M S_{t-j}^{-}+ \\
+\varphi_{j}^{+} \Delta L I R_{t-j}^{+}+\varphi_{j}^{-} \Delta L I R_{t-j}^{-} \\
+\varepsilon_{t} .
\end{array}\right)+
\end{gathered}
$$

In equation (13), $p$ and $q$ are the lag order of endogenous and exogenous variables, respectively. The coefficients $\left(\omega_{1}^{+}, \omega_{2}^{-}, \omega_{3}^{+}, \omega_{4}^{-}, \omega_{5}^{+}, \omega_{6}^{-}, \omega_{7}^{+}\right.$, $\omega_{8}^{-}$) represent the long-run relationship, whereas coefficients $\sum_{j=0}^{q-1}\left[\theta_{j}^{+}, \theta_{j}^{-}, \pi_{j}^{+}, \pi_{j}^{-}, \phi_{j}^{+}, \phi_{j}^{-}, \varphi_{j}^{+}, \varphi_{j}^{-}\right] \quad$ represent the short-term dynamics of the model. However, $\beta_{1}^{+}=\left[-\frac{\omega_{1}^{+}}{\rho}\right], \quad \beta_{2}^{-}=\left[-\frac{\omega_{2}^{-}}{\rho}\right], \quad \beta_{3}^{+}=\left[-\frac{\omega_{3}^{+}}{\rho}\right]$, $\beta_{4}^{-}=\left[-\frac{\omega_{4}^{-}}{\rho}\right], \quad \beta_{5}^{+}=\left[-\frac{\omega_{5}^{+}}{\rho}\right], \quad \beta_{6}^{-}=\left[-\frac{\omega_{6}^{-}}{\rho}\right]$, $\beta_{7}^{+}=\left[-\frac{\omega_{7}^{+}}{\rho}\right] \& \beta_{8}^{-}=\left[-\frac{\omega_{8}^{-}}{\rho}\right]$ are the asymmetric long-run elasticities for $\mathrm{CFD}^{+}, \mathrm{CFD}^{-}, \mathrm{OP}^{+}, \mathrm{OP}^{-}, \mathrm{GrMS}^{+}$, $G r M S^{-}, L I R^{+} \& L I R^{-}$, respectively, on CAD. $\varepsilon_{t}$ is the white noise (i. e., error term normally distributed around zero mean and constant variance).

For estimating asymmetric cointegration among the variables, the joint null hypothesis of no cointegration, $\rho=\omega_{1}^{+}=\omega_{2}^{-}=\omega_{3}^{+}=\omega_{4}^{-}=\omega_{5}^{+}=$ $=\omega_{6}^{-}=\omega_{7}^{+}=\omega_{8}^{-}=0$ is tested using the bounds testing approach based on the F-statistics. If the value of the ${ }^{\mathrm{F}}$-statistics is larger than the upper bound critical value, it confirms the existence of long-run relationship between the variables; if the value is below the lower bound, it negates any relationship. The test is inconclusive if the value of the F-statistics lies between the two bounds. To estimate the short- and long-run asymmetric effect, we adopted the Wald statistics.

\subsection{Empirical Analysis}

For the implementation of the NARDL approach, it is mandatory to verify the order of integration of all variables. From Table 2, $A D F$ and $P P$ tests show that GrMS is stationary at levels, i. e. $I(0)$, and the rest of the variables are stationary at first difference, i. e. I(1). Therefore, different order of integration, i. e. I(0) and I(1), vali- 
Cointegration Test (Bounds Test)

\begin{tabular}{|c|c|c|c|c|c|}
\hline \multirow{2}{*}{ Equation } & \multirow{2}{*}{$\boldsymbol{F}_{p s s}$} & Level of significance & \multicolumn{2}{|c|}{ Critical Value } & \multirow{2}{*}{ Results } \\
\cline { 3 - 5 } & & & Lower bounds & Upper bounds & \\
\hline $\begin{array}{l}W P I=f\left(\mathrm{CFD}^{+}, \mathrm{CFD}^{-}, \mathrm{OP}^{+}, \mathrm{OP}^{-},\right. \\
\mathrm{GrMS}^{+}, \mathrm{GrMS}^{-}, \mathrm{LIR}^{+}, \mathrm{LIR}^{-}\end{array}$ & \multirow{2}{*}{4.63} & 5 percent & 2.94 & 4.08 & Cointegration \\
\cline { 3 - 5 } & & 10 percent & 2.46 & 3.46 & Cointegration \\
\hline
\end{tabular}

Source: Author's compilation.

Note: the critical values are taken from [47].

Diagnostic Tests

\begin{tabular}{|l|c|c|}
\hline Residuals Diagnostic Test & Statistics & $\boldsymbol{p}$-value \\
\hline Serial Correlation test & 26.15 & 0.10 \\
\hline Heteroskedasticity test & 0.62 & 0.42 \\
\hline Normality Test & 0.45 & 0.80 \\
\hline
\end{tabular}

Source: Author's compilation.

Asymmetry Statistics

\begin{tabular}{|c|c|c|c|c|}
\hline \multirow{2}{*}{$\begin{array}{c}\text { Exogenous } \\
\text { Variables }\end{array}$} & \multicolumn{2}{|c|}{$\begin{array}{c}\text { Long Run } \\
\text { Asymmetry }\end{array}$} & \multicolumn{2}{c|}{$\begin{array}{c}\text { Short Run } \\
\text { Asymmetry }\end{array}$} \\
\cline { 2 - 5 } & $\boldsymbol{F}$-stat & $\boldsymbol{P}$-value & $\boldsymbol{F}$-stat & $\boldsymbol{P}$-value \\
\hline CFD & $13.36^{* *}$ & 0.00 & 0.94 & 0.36 \\
\hline OP & $4.52^{* * *}$ & 0.07 & 3.03 & 0.12 \\
\hline$G r M S$ & 1.03 & 0.34 & 0.38 & 0.56 \\
\hline LIR & 2.70 & 0.14 & 0.04 & 0.85 \\
\hline
\end{tabular}

Source: Author's compilation.

Note: ${ }^{* *} \&^{* * *}$ represent $5 \& 10$ percent level of significance.

dates the implementation of the NARDL approach to cointegration.

The study has used the FPSS statistic of [47] to detect asymmetric cointegration among the variables; the results are reported in Table 6 . This test provides reliable results on asymmetric cointegration by including different orders of assimilation [48].

Since the calculated value of the FPSS statistics (4.63) is greater than the upper bounds critical values at 5 percent level of significance, we rejected the null hypothesis of no asymmetric cointegration among the variables.

Before estimating the NARDL model, we conducted some diagnostic tests to check the suitability of the model (see table 7). The Breusch-Godfrey serial correlation LM test and the Breusch-PaganGodfrey test reveal that the model is free from the problem of autocorrelation and heteroskedasticity in the residuals, respectively. The Jarque-Bera statistics show that the residual term is normally distributed.

Further, we employed the Wald test to scrutinise both long-run and short-run asymmetries to validate the NARDL approach and the outcomes of the long-and short-run asymmetries are reported in Table 8 . The results support the exist- ence of long-run asymmetries between the negative and positive parts of fiscal deficit (CFD) and oil prices $(O P)$. Furthermore, the findings of shortrun asymmetry reveal that the Wald test failed to reject the null hypothesis of short-run symmetries between the negative and positive parts of all variables.

Following the general to specific method, the study estimates the NARDL model shown in equation (13); the results of long-run estimates are reported in Table 9. The results show that the influence of positive and negative changes in CFD on WPI appears to be positive, and it is significant at 5 and 10 percent level of significance, respectively. This result is similar to other studies, including [1; $20 ; 22 ; 27-30]$. The obtained results indicate that a 1 percent increase in $F D$ will lead to a 4.70 percentage point increase in WPI, whereas a 1 percent decrease in $F D$ will lead to a 3.93 percentage point decrease in WPI. However, the positive change in $F D$ has a larger influence on WPI compared to the negative change in $F D$.

Another essential element in determining the price level is the growth rate of the money supply. As shown in Table 9, positive and negative parts of GrMS have no asymmetries in the long run as well as in the short run. The impact of positive and negative change in GrMS on WPI is insignificant, indicating no direct relationship. This result is contradictory to the theory of monetarists, which argued that inflation is always a monetary phenomenon. The above-mentioned findings, i. e., a positive and significant relationship between fiscal deficit and inflation and no association between money supply and inflation support the fiscal theory of the price level in India. According to this theoretical paradigm, the fiscal deficit is the main factor responsible for influencing inflation, and money supply plays no significant role in determining inflation. The dominance of the fiscal policy over monetary policy along with an increase in government liabilities restrict the commitment of the Central Bank to achieve price-level stability.

The next important factor considered in the model for determining inflation is oil prices. We found that positive changes in $O P$ have a positive and significant impact on inflation at 5 percent 
Table 9

Long-Run Coefficients

\begin{tabular}{|c|c|c|c|}
\hline Variables & Coefficients & $\boldsymbol{F}$-stat & $\boldsymbol{p}$-value \\
\hline$C F D^{+}$ & $4.70^{* *}$ & 8.81 & 0.02 \\
\hline$C F D^{-}$ & $3.93^{* * *}$ & 4.31 & 0.07 \\
\hline$O P^{+}$ & $0.49^{*}$ & 32.76 & 0.00 \\
\hline$O P^{-}$ & -0.22 & 3.86 & 0.10 \\
\hline$G r M S^{+}$ & 0.18 & 0.15 & 0.71 \\
\hline$G r M S^{-}$ & 0.48 & 0.70 & 0.43 \\
\hline$L I R^{+}$ & -1.68 & 1.6 & 0.24 \\
\hline$L I R^{-}$ & $-1.23^{* * *}$ & 3.79 & 0.09 \\
\hline$E C M(-1)$ & $-0.62^{*}$ & $t$-stat $=-4.07$ & 0.00 \\
\hline
\end{tabular}

Source: Author's compilation.

Note: ", " \& "**t represent 1, 5 \& 10 percent level of significance.

level of significance, whereas a negative change in $O P$ has a negative but insignificant impact on inflation at 5 percent level of significance. This indicates that a 1 percent increase in $O P$ will lead to a 0.49 percentage point increase in WPI in the long run. The result obtained here is in line with results presented by [39-41] etc.

Interest rate also plays a vital role in determining the price level in the economy. The positive and negative parts of interest rate failed to reject the null hypothesis of no asymmetries both in the long-run and short-run. We found that a positive change in $L I R$ appears to have a negative effect on WPI, but it is insignificant at 5 percent level of significance, whereas, a negative change in LIR has a negative impact on WPI that is significant at 10 percent level of significance. This implies that a 1 percent decrease in $L I R$ will lead to a 1.23 percentage point increase in WPI in the long run. This supports the Keynes' version of the quantity theory of money, which argued that the central bank makes policy changes by increasing interest rate in order to control the price level of the economy.

Lastly, the verification of the short-term dynamics is also important. The error correction term $(E C M)$ is negative significant at 5 percent level of significance, confirming the long-run relationship between WPI and its covariates. Here, the coefficient is -0.62 , which shows that the speed of adjustment towards long-run equilibrium is 62 percent annually. Concisely, the study concludes that the assumption of a symmetrical relation between fiscal deficit and inflation could lead to misleading inferences. Notable, both negative and positive changes in the fiscal deficit have a differential impact on inflation in the long run.

\section{Conclusion and Suggestions}

The present study estimates the impact of the fiscal deficit on inflation in India using annual datasets for the period from 1980-81 to 2016-17.
The study has considered additional macroeconomic variables namely, money supply, oil prices, and lending interest rates as the determinants of inflation. For empirical analysis, we used the ARDL and NARDL approaches. To check the stationarity of all macroeconomic variables, we applied the Augmented Dickey-Fuller $(A D F)$ test and Phillips-Perron $(P P)$ test. ADF and PP tests showed that GrMS is stationary at levels, i. e. I(0), and the rest of the variables are stationary at the first difference, i. e. I(I), which allowed us to apply the ARDL and NARDL models. The ARDL approach found no evidence of linear relationship between fiscal deficit and inflation in the Indian context. Therefore, we used the NARDL model to verify the nonlinear/asymmetric relationship between the variables. The NARDL approach distinguishes the positive and negative changes in explanatory variables for estimating the response in the dependent variable.

We obtained the following results after using the NARDL model. First, the bounds test confirmed the asymmetric cointegration among the selected variables since the FPSS statistic is higher than the critical upper bound value at 5 percent level of significance. Second, the Wald test found asymmetries between the negative and positive parts of the fiscal deficit $(C F D)$ and oil prices $(O P)$ in the long run only. Third, the impact of positive and negative changes in FD on WPI appears to be positive and significant. These results are akin to those of $[1 ; 20 ; 22 ; 27-30]$. The impacts of positive and negative parts of money supply have no asymmetries in both long run and short run. The impact of positive and negative changes in money supply on WPI is insignificant, indicating no direct relationship. This result is contradictory to the theory of monetarists, which argued that inflation is always and everywhere a monetary phenomenon. The above-mentioned findings, i. e., a positive and significant relationship between fiscal deficit and inflation and no association between money supply and inflation support the fiscal theory of the price level in India's case. Fourth, the impact of both positive and negative changes in oil prices on WPI is positive and significant. This result supports many theoretical and empirical studies, including [39-41]. Lastly, the coefficient of ECM is 0.62, meaning that the speed of adjustment towards long-run equilibrium is 62 percent annually.

Fiscal policy plays a vital role in controlling price fluctuations by contractionary and expansionary fiscal policy. Presently, India is facing recession due to depreciation of the rupee, high interest payment on borrowings and increase in oil 
and petrol prices in the international market, resulting in a decline in industrial production and, hence, increase in unemployment. Therefore, this study suggests that the government should adopt expansionary fiscal policy by reducing taxes for the manufacturing sector and investing in infrastructure, electricity, health, education, to boost the demand, which will stimulate private players to produce more. This action will have a long-term stabilising effect on the Indian economy. It will increase production results and purchasing power by providing people with employment, decrease inflationary pressure by reducing the demand and supply mismatch, and help curb inflation.

\section{References}

1. Parida, P. C., Mallick, H. \& Mathiyazhagan, M. K. (2001). Fiscal deficits, money supply and price level: empirical evidence from India. Journal of Indian School of Political Economy, 13(4), 583-93.

2. Friedman, M. (1968). Dollars and deficits: inflation, monetary policy and the balance of payments (No. 332.4/F91d). Prentice Hall, 259.

3. Sargent, T. J. \& Wallace, N. (1981). Some unpleasant monetarist arithmetic. Federal Reserve Bank of Minneapolis quarterly review, 5(3), 1-17.

4. Fischer, S. \& Easterly, W. (1990). The economics of the government budget constraint. The World Bank Research Observer, 5(2), 127-142.

5. Miller, P. J. (1983). Higher deficit policies lead to higher inflation. Federal Reserve Bank of Minneapolis Quarterly Review, 7(1), 8-19.

6. Raj, J., Khundrakpam, J. K. \& Das, D. (2011). An empirical analysis of monetary and fiscal policy interaction in India. RBI Working Paper Series, WPS (DEPR): 15/2011.

7. RBI. (2012). Fiscal and Monetary Coordination. Report on Currency and Finance 2009-2012.

8. Hamburger, M. J. \& Zwick, B. (1981). Deficits, money and inflation. Journal of Monetary Economics, 7(1), $141-150$.

9. Levy, M. D. (1981). Factors affecting monetary policy in an era of inflation. Journal of Monetary Economics, 8(3), 351-373.

10. Ahking, F. W. \& Miller, S. M. (1985). The relationship between government deficits, money growth and inflation. Journal of macroeconomics, 7(4), 447-467.

11. Darrat, A. F. (1985). Inflation and federal budget deficits: some empirical results. Public Finance Quarterly, 13(2), 206-215.

12. Eisner, R. \& Pieper, P. J. (1984). A new view of the federal debt and budget deficits. The American Economic Review, 74(1), 11-29.

13. Choudhary, M. A. \&Parai, A. K. (1991). Budget deficit and inflation: the Peruvian experience. Applied Economics, 23(6), 1117-1121.

14. Shabbir, T., Ahmed, A. \& Ali, M. S. (1994). Are government budget deficits inflationary? Evidence from Pakistan. The Pakistan Development Review, 33(4), 955-967.

15. Chaudhary, M. A., Ahmad, N. \& Siddiqui, R. (1995). Money Supply, Deficit, and Inflation in Pakistan. The Pakistan Development Review, 34(4), 945-956.

16. Metin, K. (1998). The relationship between inflation and the budget deficit in Turkey. Journal of Business \& Economic Statistics, 16(4), 412-422.

17. Darrat, A. F. (2000). Are budget deficits inflationary? A reconsideration of the evidence. Applied Economics Letters, 7(10), 633-636.

18. Solomon, M. \& de Wet, W. A. (2004). The effect of a budget deficit on inflation: The case of Tanzania. South African Journal of Economic and Management Sciences, 7(1), 100-116.

19. Alavirad, A. \&Athawale, S. (2005). The impact of the budget deficit on inflation in the Islamic Republic of Iran. OPEC review, 29(1), 37-49.

20. Catao, L. A. \&Terrones, M. E. (2005). Fiscal deficits and inflation. Journal of Monetary Economics, 52(3), $529-554$.

21. Vamvoukas, G. A. \& Gargalas, V. N. (2008). Testing Keynesian Proposition And Ricardian Equivalence: More Evidence on The Debate. Journal of Business and Economic Research, 6(5), 67-76.

22. Khundrakpam, J. K. \& Pattanaik, S. (2010). Fiscal stimulus and potential inflationary risks: An empirical assessment of fiscal deficit and inflation relationship in India. Journal of Economic Integration, 25, 703-721.

23. Milo, P. (2012). The impact of the budget deficit on the currency and inflation in the transition economies. Journal of Central Banking Theory and Practice, 1(1), 25-57.

24. Dhal, S. (2015). The inflation impact of bonds versus money financing of fiscal deficits in India: some theoretical and empirical perspectives. Macroeconomics and Finance in Emerging Market Economies, 8(1-2), 167-184.

25. Nguyen, B. (2015). Effects of fiscal deficit and money M2 supply on inflation: Evidence from selected economies of Asia. Journal of Economics, Finance and Administrative Science, 20, 49-53.

26. Saunders, P. J. (1989). Federal Budget Deficits, Interest Rates, and Inflation: Their Implication for Growth. Eastern Economic Journal, 15(3), 213-219.

27. Ramu, M. A. \& Gayithri, K. (2017). Fiscal deficit and inflation linkages in India: tracking the transmission channels. Journal of Social and Economic Development, 19(1), 1-24. 
28. Bhat, J. \& Sharma, N. K. (2018). Identifying Fiscal Inflation in India-Some Recent Evidence from an Asymmetric Approach. Journal of Economics, Finance and Administrative Science, 25(50).

29. Kaur, G. (2019). Inflation and Fiscal Deficit in India: An ARDL Approach. Global Business Review, 1-21.

30. Sriyana, J. \& Ge, J. J. (2019). Asymmetric responses of fiscal policy to the inflation rate in Indonesia. Economics Bulletin, 39(3), 1701-1713.

31. Dwyer Jr, G. P. (1982). Inflation and government deficits. Economic Inquiry, 20(3), 315-329.

32. Karras, G. (1994). Macroeconomic effects of budget deficits: further international evidence. Journal of International Money and Finance, 13(2), 190-210.

33. Khieu, H. (2014). Budget deficit, money growth and inflation: Empirical evidence from Vietnam. MPRA Paper, 54488. Germany: University Library of Munich, 34.

34. Tiwari, A. K., Bolat, S. \& Koçbulut, Ö. (2015). Revisit the Budget Deficits and Inflation: Evidence from Time and Frequency Domain Analyses. Theoretical Economics Letters, 5, 357-369.

35. Chakraborty, L. \& Varma, K. O. (2018). Fiscal reforms, deficits and inflation determination: Empirical evidence from India. Prajnan, 46(4), 353-371.

36. Rami, G. (2010). Causality between money, prices and output in India (1951-2005): A granger causality approach. Journal of quantitative economics, 8(2), 20-41.

37. Bhaduri, S. \& Durai, S. R. S. (2012). A note on excess money growth and inflation dynamics: evidence from threshold regression. MPRA Paper No. 38036. Munich, Germany: Munich Personal RePEc Archive, 8.

38. Bhattacharya, K. \& Bhattacharyya, I. (2001). Impact of increase in oil prices on inflation and output in India. Economic and Political weekly, 36, 4735-4741.

39. Raj, J., Dhal, S. \& Jain, R. (2008). Imported inflation: The evidence from India. RBI Occasional Papers, 29(3), 69-117.

40. Bhanumurthy, N. R., Das, S. \& Bose, S. (2012). Oil price shock, pass-through policy and its impact on India. NIPFP Working Paper No-99, 54.

41. Mohanty, D. \& John, J. (2015). Determinants of inflation in India. Journal of Asian Economics, 36, 86-96.

42. Pesaran, M. H. \& Shin, Y. (1998). An autoregressive distributed-lag modelling approach to cointegration analysis. Econometric Society Monographs, 31, 371-413.

43. Shin, Y., Yu, B. \& Greenwood-Nimmo, M. (2014). Modelling asymmetric cointegration and dynamic multipliers in a nonlinear ARDL framework. In: Festschrift in honor of Peter Schmidt (pp. 281-314). Springer, New York, NY.

44. Pattnaik, R. K. \& Samantaraya, A. (2006). Indian experience of inflation: A review of the evolving process. Economic and Political Weekly, 41(4), 349-357.

45. Dickey, D. A. \& Fuller, W. A. (1979). Distribution of the estimators for autoregressive time series with a unit root. Journal of the American statistical association, 74(366a), 427-431.

46. Phillips, P. C. \& Perron, P. (1988). Testing for a unit root in time series regression. Biometrika, 75(2), 335-346.

47. Pesaran, M. H., Shin, Y. \& Smith, R. J. (2001). Bounds testing approaches to the analysis of level relationships. Journal of applied econometrics, 16(3), 289-326.

48. Sharma, V. \& Mittal, A. (2019). Fiscal deficit, capital formation, and economic growth in India: a non-linear ARDL model. Decision, 46(4), 353-363.

\section{About the authors}

Vishal Sharma - PhD in Economics, Assistant Professor, Institute of Business Management, GLA University; https:// orcid.org/0000-0003-3612-7241 (Mathura, India; e-mail: economics.vishal26@gmail.com).

Ashok Mittal - PhD in Economics, Professor, Department of Economics, Aligarh Muslim University (Aligarh, India; e-mail: askmittal@yahoo.com).

\section{Информация об авторах}

Шарма Вишал - PhD в области экономических наук, доцент, институт управления бизнесом, Университет GLA; https://orcid.org/0000-0003-3612-7241 (Матхура, Индия; e-mail: economics.vishal26@gmail.com).

Миттал Ашок - PhD в области экономических наук, профессор, кафедра экономики, Алигархский мусульманский университет (Алигарх, Индия; e-mail: askmittal@yahoo.com).

Дата поступления рукописи: 04.06.2020.

Прошла рецензирование: 01.10.2020.

Принято решение о публикации: 18.12.2020.

Received: 04 June 2020

Reviewed: 01 Oct 2020

Accepted: 18 Dec 2020 